\title{
The Effects of Socio-Economic Status on Drinking and Smoking in Korean Adolescents
}

\author{
Sun-hee Cho, Ae-yong Eom, Gyeong-Suk Jeon ${ }^{\dagger}$ \\ Department of Nursing, Mokpo National University
}

\begin{abstract}
$<$ Abstract $>$
There is growing evidence that substance use such as tobacco or alcohol consumption influences health disparity among adolescents. Previous research papers have shown an inconsistency in the relationship between socio-economic status (SES) and substance use in adolescents. However, little is known about socio-economic differences in unhealthy behaviors among Korean adolescents. The purpose of the present study is to explore associations between SES and substance use in Korean adolescents. The analysis was performed using data from the 2009 Korean Youth Risk Behavior Web-based Survey (YRBS), which included a nationally representative sample of middle and high school students. Drinking/heavy drinking and smoking/daily smoking behavior indices were used for dependent variables, and perceived economic status, family affluence score, parents' education were used for independent variables. Chi-square test were used to compare tobacco and alcohol consumption among 3 SES groups. Logistic regression models were used to identify statistically significant socio-economic factors after adjusting other covariates. Higher perceived economic status and higher family affluence were associated with higher rates of smoking, daily smoking, drinking, and heavy drinking, while lower level of parents' education was related to higher use of tobacco and alcohol. Socio-economic status significantly influences health behaviors in adolescents, and it may consequently affect health disparity in their adulthood. Therefore, there is a need of continuous monitoring and follow-up research of health disparity among adolescents.
\end{abstract}

Key Words : Adolescent, Smoking, Drinking, Socioeconomic Status, Health Inequality 


\section{I . 서론}

1. 연구의 필요성

2011년 중· 고등학생의 음주율은 $20.6 \%$, 흡연율 은 $12.1 \%$ 로 10 명중 2 명은 음주를 그리고 10 명중 1 명은 흡연을 하고 있는 것으로 보고되고 있어[1] 매우 큰 사회적 관심을 필요로 한다. 우리나라의 청소년 흡연율은 다른 $\mathrm{OECD}$ 국가에 비해 높은 수 준이고, 흡연연령도 점차 낮아지고 있어 청소년의 건강은 물론 가정과 학교에서 문제를 일으키는 사 회문제가 되고 있다[2].

청소년기는 급격한 신체적 성장과 더불어 정서 적 및 사회적 민감도가 높으며 자아주체성과 자아 의식이 완전히 확립되지 않아 주변 환경의 영향에 매우 밀접하게 반응하는 시기이므로 술과 담배를 포함한 약물의 의존에 취약성을 갖게 된다[3]. 청 소년기에는 성인보다 적은 양의 알코올 섭취로도 신체는 물론 정신적 건강상에 큰 문제들을 야기시 키며, 청소년기에 음주를 시작하는 경우 성인이 되 어서도 고위험 음주를 할 확률이 매우 높다[4]. 더 불어 청소년 흡연의 경우 16 세 이하에서 담배를 피우는 경우 그 피해는 20세 이후에 담배를 시작 하는 경우보다 피해 정도가 3 배 더 높은 것으로 보고되었으며, 16 세 이하에서 담배를 피우기 시작 한 사람의 폐암사망률은 담배를 피우지 않는 사람 에 비해 27배나 높은 것으로 나타났다[5].

이러한 청소년의 음주와 흡연은 청소년 비행 행 동에 영향을 미치고 있는 사회문제이며 청소년 건 강의 중요한 보건의료 문제이다[6]. 실제로 청소년 들이 흡연 후 가족 내에서 갈등의 마찰이 있으며, 학교에서는 또래와의 폭력문제로 확장되고, 개인적 으로는 신체적 건강문제로 야기되어 학습장애가 발생되며 인간관계의 어려움을 경험하는 부정적인 비율이 높아진 것으로 나타났으며, 흡연은 비행친 구들과 어울리는 중요한 매개체로서 역할을 하는
것으로 보고되고 있다[7]. 또한, 청소년 흡연은 개 인의 건강한 심리사회적 발달을 저해하는 위험요 인으로 지적되고 있는데 흡연을 지속적으로 한 청 소년에게서 우울증상, 충동장애, 품행장애, 주의력 결핍장애 등 정서적으로도 영향을 미친다고 하였 다[2].

청소년의 음주 및 흡연에 영향을 미치는 요인에 는 부모 또는 친구의 흡연여부에 따른 모방심리 및 동료에의 동조성, 부모와의 관계만족도, 부모의 사회경제적 수준, 학교생활만족 및 학업성취도, 심 리적 갈등, 긴장완화, 부모나 교사와 같은 권위자 에 대한 반항 등 사회심리적 요인이 복합적으로 관련성이 있었다[6][7][8]. 이와 같이 사회적 및 심 리적의 요인들이 청소년의 음주 및 흡연에 영향을 미치는 요인으로 밝혀졌으며 그중에서 부모의 사 회경제적 상태가 어떠한 상관성이 있는지 구체적 으로 살펴볼 필요가 있다. 왜냐하면 사회경제적 지 위의 상태는 건강수준뿐만 아니라, 건강행위 실천 수준과도 상관성이 있다는 연구결과[7][8]에 따라 사회경제적 요인이 건강에 영향을 주는 강력한 예 측요인으로 보기 때문이다.

교육 수준과 소득이 건강행위를 증진시킨다는 근거들은 이미 선행연구에서 밝힌바 있으며 교육 수준은 가장 널리 쓰이는 사회경제적 지위이며 이 는 건강행위와 밀접한 관련이 있다[8]. 교육은 긍 정적인 건강행위의 지식에 영향을 주며, 또한 자산 과 소득은 건강한 환경으로의 접근을 용이하게 한 다[3]. 이처럼 성인에게 있어서는 교육수준, 소득, 및 직업과 같은 사회경제적 지위는 건강의 주요한 결정요인으로서 건강격차 현상이 뚜렷함이 확인되 었다. 반면 청소년기 사회경제적 건강격차에 대해 서는 여전히 불분명하다. 청소년기의 건강과 관련 된 지식, 태도, 행동 형성에는 부모의 건강행위를 비롯한 가족의 영향이 주요 역할을 하듯 부모의 사회경제적 지위 및 가구의 물질적 조건 역시 청 소년의 음주 및 흡연과 같은 건강행위에 영향을 
주기 때문에[3][8] 부모의 사회경제적 수준에 따라 청소년의 건강 및 건강행위의 격차가 존재한다는 연구가 있다. 선행 연구에 따르면 부모의 교육 수 준이 상위층인 경우 중위층이나 하위층보다 음주 율이 낮았으며 부모의 교육수준이 청소년 자녀의 음주율에 강력한 영향력을 미치고 있음을 보여주 고 있었으며[9] 12 17세 청소년을 대상으로 부모 의 사회경제적 지위와 음주 및 흡연과 건강행위와 의 관련성 연구에서[10] 가구수입과 보호자의 교육 수준이 높을수록 흡연율이 낮았으며, 부모의 교육 수준과 가구 수입이 낮을수록 청소년 자녀의 흡연 율이 높게 나타난 현상은 사회경제적 지위가 낮은 계층에서 청소년기의 건강행위에 미치는 영향에 관한 관리 전반적으로 낮음을 보고하고 있다. 그리 고 부모의 사회경제적 지위를 가구평균소득으로 측정하여 비행유형과 상관관계를 분석한 결과를 보면[6] 부모의 사회경제적 지위를 부와 학력으로 측정했을 때 청소년의 음주 및 흡연과 연관된 비 행이 관련이 있었다. 결과적으로 청소년의 건강 및 건강행태 특히 흡연, 음주의 독립적 결정요인으로 써 서로 다른 사회경제적 지표의 상대적 중요성에 대해 일치되지 않았다. 기존 연구들은 단일 사회경 제적 위치 요인을 사용하여 타 연구결과와 비교하 는 수준이거나, 청소년의 흡연, 음주에 영향하는 다른 주요 요인에 대한 고려없이 단순 사회경제적 위치의 영향만을 확인하는 수준이었다. 따라서 부 모의 사회경제적 위치 및 청소년 자신이 평가하는 사회경제적 위치를 포함한 다양한 사회경제적 위 치가 청소년의 흡연, 음주행태에 미치는 독립적 영 향 정도를 정확히 비교분석하여 탐색해볼 필요가 있다.

\section{2. 연구의 목적}

본 연구의 목적은 청소년의 다양한 사회경제적 수준이 흡연 및 음주에 미치는 영향을 탐색함으로
써 흡연, 음주와 같은 불건강한 건강행위의 취약그 룹을 알아내고 청소년의 음주 및 흡연예방 또는 치료 프로그램의 접근 방향에 대한 근거를 마련하 는데 기초자료를 제공하고자 한다. 본 연구의 구체 적인 목적은 다음과 같다.

첫째, 청소년의 부모의 사회경제적 수준 및 청 소년 자신이 평가한 사회경제적 수준을 확인한다.

둘째, 다양한 사회경제적 수준에 따른 흡연, 음 주 수준을 비교 분석한다.

셋째, 청소년의 흡연, 음주에의 다양한 사회경제 적 위치의 독립적 영향정도를 비교 탐색한다.

\section{ㅍ. 연구방법}

1. 연구자료 및 연구대상

본 연구는 교육과학기술부, 보건복지부 및 질병 관리본부가 공동으로 실시한 「2009년 청소년 건 강행태 온라인 조사」 자료를 활용하였다. 조사대상 은 전국 중학교 1학년에서 고등학교 3학년까지의 학생을 대상으로 16 개 시·도내의 시·군·구를 대도 시, 중·소도시, 군지역으로 분류하여 45 개 시군구 를 집락화 하였으며 집락별 할당된 표본 수만큼 계통추출법으로 400 개의 중학교와 400 개의 고등학 교를 추출하였다. 2 단계로 추출된 표본학교의 각 학년 당 1 개 학급을 표본학급으로 선정하여 학교 당 3 개의 표본 학급을 선정하였다. 선정된 학급의 학생 전원은 표본학생이 되었다. 단 장기결석, 특 수아동 및 문자해독장애 학생은 조사대상에서 제 외되어 총 표본대상 76,937 명에서 실제 조사에 참 여한 학생은 75,066 명으로 조사대상자의 응답율은 $97.6 \%$ 가 되었다[13]. 본 연구를 위한 최종 분석 대 상자는 중학교 1학년에서 고등학교 3학년 전체조 사대상자 중 주요변수(주관적 사회경제적 수준, 부 의 학력, 모의 학력, 가족 풍요도)에 있어서의 결측 사례를 제외한 총 69,196명(남자 36,137명, 여자 
33,060명)으로 하였다.

청소년 온라인 보건행태조사의 내용은 흡연, 음 주, 비만 및 체중조절, 신체활동, 식습관, 손상예방, 약물, 성행태, 정신보건, 구강보건, 개인위생, 아토 피·천식, 인터넷 중독, 건강형평성 등을 14 개영역 의 129 개 문항으로 구성되었으며 설문문항 및 지 표는 국내·외 자료에 근거를 두고 각 영역별 분과 자문위원회를 통해 개발되었으며 조사는 질병관리 본부의 조사 진행 지침에 따라 (표본학급 담임교사 입실 불가능, 학생들이 사용하는 컴퓨터 화면 보기 금지, 설문문항 질문에 관한 답변 금지 등) 조사지 원 담당교사에 의해 수행되었다. 조사 전체 과정은 수업시간 45 50분 동안 진행되었으며, 성실한 응 답확보를 위해 설문조사 완료 후 학생들에게 답례 품을 지급되었다.

\section{2. 변수의 측정}

\section{1) 흡연, 매일흡연, 음주 및 과도음주}

종속변수에는 흡연의 시작을 의미하는 '흡연경 험', 흡연의 지속을 의미하는 '매일흡연', 음주의 시 작을 의미하는 '음주경험', 음주의 지속을 의미하는 '과도음주'를 포함하였다. 흡연 경험은 평생 동안 담배를 한 두 모금이라도 피운 경험이 있는 사람 의 분율로써 "지금까지 담배를 한 두 모금이라도 피워본 적이 있습니까?” 로 질문하여 '있음'과 '없 음으로 구분하여 응답하게 하였다. 매일흡연은 최 근 30 일 동안 매일 흡연한사람의 분율로써 “최근 30 일 동안, 담배를 한 대(한 개비)라도 피운 날은 며칠입니까?" 로 질문에 (1) 최근 30일 동안 담배 를 피워본 날이 없다' (2) '월 1 2일' (3) '월 3 5 일' (4) '월6 9일' (5)'월 10 19일' (6) '월 20 29일' (7)'매일'의 응답이 주어졌다. 7번에 응답한 학생을 매일 흡연으로 분류하였다. 음주 경험은 평생 동안 1 잔 이상 술을 마셔본 적이 있는 사람의 분율로써 “지금까지 1 잔 이상 술을 마셔본 적이 있습니까?"
로 질문하여 '있음'과 '없음'으로 구분하여 응답하 게 하였고 '과도음주'는 현재 음주자 중에서 최근 30 일 동안 1 회 평균 음주량이 과량인 사람의 분율 로써 “최근 30일 동안, 술을 마실 때 평균량은 얼 마입니까?"라고 질문하여 (1)소주1 2잔(맥주1병 이 하) (2)소주3 4잔(맥주2병, 양주3잔) (3)소주 5 6잔 (맥주 3병, 양주5잔) (4)소주1병 2병 미만(맥주4병, 양주6잔) (5) 소주2병 이상(맥주8병, 양주12잔)의 응답이 주어졌다. 남학생의 경우 '과도음주'를 (4) 소주1병 2병 미만(맥주4병, 양주6잔) 와 (5)소주2병 이상(맥주8병, 양주12잔)이라고 응답한 경우로 하 였으며 여학생의 '과도음주'는 (3) 소주5 6잔 이상 (맥주 3병, 양주5잔), (4)소주1병 2병 미만(맥주4병, 양주6잔)와 (5)소주2병 이상(맥주8병, 양주12잔)에 응답한 경우로 분류하였다.

2) 사회경제적 수준

사회경제적 수준의 측정은 학생이 인지한 가구 의 경제수준, 가구 풍요도, 부의 교육수준 및 모의 교육수준으로 하였다. 주관적 가구경제 수준은 상, 중상, 중, 중하, 하의 5 개의 응답항목을 '상(상, 중 상)', '중', '하(중하, 하)'의 세 그룹으로 재분류하여 사용하였다. 가구 풍요도(family affluence scale)는 자동차 보유 대수(없음:0점, 1대: 1점, 2대 이:2점) 자기 방 소유 여부(없음:0점, 있음:1점), 지난 일 년 간 주말 동안 가족여행을 한 횟수(전혀 없음:0점, 1 회:1점, 2회:2점, 3회 이상:3점), 학생 가정의 컴퓨터 보유 대수(없음:0점, 1대:1점, 2대:2점, 3대:3점)의 4 개의 문항으로 측정하여 각 문항의 점수를 합한 총점을 상위 계층은 6-9점, 중간층은 3-5점, 하위 계층은 0-2점으로 구분하였다. 부모의 교육수준은 각각 '대학교 졸업 이상', '고등학교 졸업', '중학교 졸업 이하' 및 '잘모름'으로 구분하였다.

3) 기타변수

기존 연구에서 청소년의 흡연 및 음주에 영향을 
미치는 요인으로 확인된 거주지역, 학년, 주관적 학업 성취도, 부모와의 동거여부, 주관적 건강상태 를 포함하였다[18][20][21]. 거주 지역은 대도시, 중 소도시, 군 지역으로 나누었으며 주관적 학업 성취 도는 "최근 12 개월 동안, 학업 성적은 어떻습니 까?"라고 질문을 했을 때, '상', '중상', '중', '중하', '하'의 응답이 주어졌다. 부모와의 동거여부는 '아 버지와 어머니 모두 같이 산다', '아버지와만 같이 산다', '어머니와만 같이 산다', '부모님과 같이 살 지 않는다', '부(모)와 양모(양부)와 동거한다'의 5 가지 경우로 분류하였다. 주관적 건강 상태는 “평 상시 자신의 건강상태가 어떻다고 생각하십니까?" 라고 질문 했을 때, 매우 '건강한 편이다', '건강한 편이다', '보통이다', '건강하지 못한 편이다', '매우 건강하지 못한 편이다’라고 5 가지의 척도로 측정하 였다.

\section{3. 분석방법}

대상자의 성별 인구학적 및 사회경제적 분포의 특성을 살피고 사회경제적 위치 지표에 따른 흡연, 음주의 수준을 확인하기 위해 Chi-square test 및 t- test를 활용하였다. 사회경제적 위치의 흡연, 음 주에의 영향정도를 탐색하기 위해 다중 로지스틱 회귀분석들 수행하였다. Chi-square test 및 t- test 의 유의수준은 0.05 를 기준으로 하였으며 로지스틱 회귀분석 시 독립변수들 간의 다중공선성 여부를 검정한 결과 모든 독립변수들의 $\mathrm{VIF}$ (variance inflation factor)는 1.532 이하로 확인되어 다중공 선성의 우려는 배재할 수 있었다. 모든 회귀분석 모형은 Hosmer-Lemeshow 모형 적합도 검정 결과 예측값과 관찰값의 차이가 유의하지 않은 것으로 나타났다. 통계분석 시에는 표본추출률과 조사완료 율을 보정하기 위한 가중치를 부여하였으며 통계 프로그램은 SPSS+ 12.0 을 이용하였다.
III. 연구결과

1. 청소년의 일반적 특성 및 사회경제적 수준

연구 대상 남학생과 여학생의 평균 연령은 각각 $15.09 \pm 1.75$ 세, $15.07 \pm 1.75$ 세 이었다. 청소년의 대부 분은 대도시(54.8\%) 및 중소도시(40.0\%)에 거주하 였으며 시골지역 거주 청소년은 단 $5.1 \%$ 에 해당하 였다. 남학생의 $12.8 \%$ 및 여학생의 $9.9 \%$ 만이 자신 의 학업성취도가 '높다'고 보고하였으며 '낮다'고 보고한 학생은 전체 $11.6 \%$ 에 해당하였다. 청소년의 $86.9 \%$ 는 친 부모님과 함께 거주한다고 응답하였으 며 전체 청소년의 $9.1 \%$ 는 편부모와 거주하였다. 한 편 편부모 중 남학생의 경우 여학생보다 편부와 거주하는 경우가 많았으며(남학생:3.0\%, 여학 생:2.6\%) 여학생의 경우 편모와 거주하는 경우가 남학생보다 많으며(남학생:5.7\%, 여학생: $7.2 \%$ ) 부모 와의 거주 형태가 성별로 유의한 차이를 보였다 $(p<0.01)$. 대부분의 학생은 '매우건강' 또는 '건강' 하다고 응답하였으나 '건강하지 않다' 및 '매우건강 하지 않다라고 응답한 남녀 학생도 각각 $6.5 \%$ 및 $9.3 \%$ 에 해당하였다. 주관적 건강평가에 있어서 유 의한 성별차이가 나타났는데 전체적으로 남학생은 여학생에 비해 자신을 건강하다고 평가하였다 $(\mathrm{p}<0.01)$.

청소년이 인지한 가구의 사회경제 수준, 풍요도 및 부·모의 교육수준으로 측정한 청소년의 사회경 제적 수준을 살펴본 결과, 남학생의 $32.1 \%$ 및 여학 생의 $25.8 \%$ 가 가구의 경제 수준을 '상'이라고 평가 하였으며 남녀 각각 $22.3 \%, 23.4 \%$ 의 학생이 가구 경제수준을 '하'라고 평가하였으며 전체적으로 남 학생은 여학생에 비해 자신 가주의 경제수준을 높 이 평가하는 경향을 보이며 성별로 유의한 차이를 나타냈다 $(p<0.01)$. 자동차 보유 대수, 자기 방 소유 여부, 지난 일 년간 주말 동안 가족여행을 한 횟수 및 학생 가정의 컴퓨터 보유 대수의 4 가지 항목으 
로 측정한 가구풍요도의 평균 점수는 $4.65 \pm 1.82$ 수 준이었으며 6점 이상의 풍요도 '상'에 해당하는 경 우는 남학생 $33.0 \%$ 여학생 $31.8 \%$ 에 해당하였으며 약 $11.5 \%$ 의 남녀학생이 풍요도 수준 '하'에 해당하 는 것으로 나타났다. 부모의 학력수준의 경우 학생 의 $44.6 \%$ 가 아버지가 대졸 졸업 이상이라고 응답 한 반면 어머니의 경우 $32.2 \%$ 만이 대졸 졸업이상 이며 약 $50 \%$ 의 학생들의 어머니가 고졸에 해당하 는 것으로 나타났다. 또한 네 가지 사회경제적 지 표들의 상관관계를 살펴본 결과 학생이 인지한 주 관적 가구경제수준과 가구 풍요도의 Spearman's correlation coefficients는 0.34 였으며 부의 학력수 준과 모의 학력수준의 상관계수는 0.64 였다. 반면, 주관적 경제수준 및 풍요도와 부모의 학력과의 상 관계수는 모두 약 0.2 수준에 해당하였다.

\section{2. 사회경제적 수준에 따른 흡연, 음주 수준}

<표 2>는 네 가지 사회경제적 수준에 따른 청 소년의 흡연, 매일흡연, 음주 및 과도음주 수준을 살펴본 결과이다. 먼저, 청소년의 흡연, 음주 수준 을 살펴보면, 남학생의 $16.4 \%$ 및 여학생의 $6.9 \%$ 가 흡연한 경험이 있는 것으로 나타났으며 남학생의 $9.1 \%$ 및 여학생의 $3.0 \%$ 는 매일 흡연하는 것으로 나타났다. 또한 남학생의 $23.0 \%$ 및 여학생의
$17.5 \%$ 가 음주경험이 있으며 과도음주 남학생은 $9.9 \%$ 여학생은 $8.8 \%$ 에 해당하였다. 흡연, 매일흡 연, 음주 및 과도음주 모두에서 남학생이 여학생에 비해 흡연, 음주 수준이 높으며 통계적으로 유의한 성별차이를 보였다 $(\mathrm{p}<0.01)$.

네 가지 사회경제적 수준에 따른 흡연, 매일흡 연, 음주 과다음주 수준을 살펴본 결과, 가구 풍요 도와 주관적 가구경제수준에 따른 건강행태의 차 이는 일관된 결과를 보이지 않았다. 하지만 부·모 의 교육수준은 남녀 모두에서 부·모의 교육수준에 따라 네 가지 건강행태 수준(흡연, 매일흡연, 음주, 과도음주)이 통계적으로 유의한 차이를 나타냈다. 즉, 가구의 물질적 조건을 측정한 가구 풍요도는 남학생의 매일흡연, 음주경험에서, 여학생의 흡연 경험, 매일흡연, 및 과도 음주에서만 통계적으로 유의한 차이를 나타냈으며 청소년이 인지한 가구 의 주관적 경제수준은 남학생의 과도음주를 제외 한 흡연경험, 매일흡연 음주경험에서만 통계적으로 유의한 차이를 나타냈다. 한편 부·모의 교육수준의 경우 남녀 학생 모두에서 부·모의 학력수준이 대 졸이상인 경우는 고졸 및 중졸이하의 경우보다 흡 연경험, 매일흡연, 음주 및 과도음주의 수준이 낮 은 것으로 나타나 부·모의 교육수준은 청소년의 흡연, 음주 수준과 유의한 관련성이 있는 것으로 확인되었다 $(\mathrm{p}<0.01)$. 
<표 1> 남자 청소년(n=36,137)과 여자 청소년 $(\mathrm{n}=33,060)$ 의 일반적 특성

\begin{tabular}{|c|c|c|c|}
\hline & 남자 $\mathrm{N}(\%)$ & 여자 $N(\%)$ & Total N(\%) \\
\hline $\mathrm{N}=$ & 36,137 & 33,060 & 69,196 \\
\hline 나이(mean \pm SD) & $15.09 \pm 1.75$ & $15.07 \pm 1.75$ & $15.07 \pm 1.75$ \\
\hline \multicolumn{4}{|l|}{ 거주 지역 } \\
\hline 농어촌 지역 & $1,862(5.2)$ & $1,684(5.1)$ & $3,546(5.1)$ \\
\hline 대도시 & $19,839(54.9)$ & $18,103(54.8)$ & $37,942(54.8)$ \\
\hline 중소도시 & $14,436(39.9)$ & $13,272(40.1)$ & $27,708(40.0)$ \\
\hline \multicolumn{4}{|l|}{ 학년 } \\
\hline 중학교 1학년 & $5,983(16.6)$ & $5,551(16.8)$ & $11,534(16.7)$ \\
\hline 중학교 2학년 & $6,179(17.1)$ & $5,666(17.1)$ & $11,845(17.1)$ \\
\hline 중학교 3학년 & $6,208(17.2)$ & $5,616(17.0)$ & $11,824(17.1)$ \\
\hline 고등학교 1학년 & $6,160(17.0)$ & $5,498(16.6)$ & $11,658(16.8)$ \\
\hline 고등학교 2학년 & $5,952(16.5)$ & $5,482(16.6)$ & $11,434(16.5)$ \\
\hline 고등학교 3학년 & $5,656(15.7)$ & $5,246(15.9)$ & $10,902(15.8)$ \\
\hline 학교 성적 & & & $* *$ \\
\hline 상 & $4,624(12.8)$ & $3,280(9.9)$ & $7,904(11.3)$ \\
\hline 중상 & $8,764(24.3)$ & $8,050(24.4)$ & $16,814(24.3)$ \\
\hline 중 & $9,809(27.1)$ & $8,985(27.2)$ & $18,794(27.2)$ \\
\hline 중하 & $8,727(24.1)$ & $8,931(27.0)$ & $17,658(25.5)$ \\
\hline 하 & $4,213(11.7)$ & $3,812(11.5)$ & $8,025(11.6)$ \\
\hline 부모와의 동거 여부 & & & $* *$ \\
\hline 양부모와 동거 & $31,604(87.5)$ & $28,558(86.4)$ & $60,162(86.9)$ \\
\hline 부와 동거 & $1,084(3.0)$ & 873(2.6) & $1,957(2.8)$ \\
\hline 모와 동거 & $2,065(5.7)$ & $2,365(7.2)$ & $4,430(6.4)$ \\
\hline 부모와 동거하지 않음 & $711(2.0)$ & $644(1.9)$ & $1,355(2.0)$ \\
\hline 친부(모) 및 계모(부)와 동거 & $671(1.9)$ & $620(1.9)$ & $1,291(1.9)$ \\
\hline 주관적 건강상태 & & & ** \\
\hline 매우 건강 & $7,780(21.8)$ & $4,545(13.7)$ & $12,425(18.0)$ \\
\hline 건강 & $17,285(47.8)$ & $15,487(46.8)$ & $32,772(47.4)$ \\
\hline 보통 & $8,623(23.9)$ & $9,966(30.1)$ & $18,589(26.9)$ \\
\hline 건강하지 않음 & $2,175(6.0)$ & $2,961(9.0)$ & $5,136(7.4)$ \\
\hline 매우 건강하지 않음 & $173(0.5)$ & $101(0.3)$ & $274(0.4)$ \\
\hline 주관적 가구 경제 상태 & & & $* *$ \\
\hline 상 & $11,581(32.1)$ & $8,527(25.8)$ & $20,108(29.1)$ \\
\hline 중 & $16,487(45.6)$ & $16,806(50.8)$ & $33,293(48.1)$ \\
\hline 하 & $8,069(22.3)$ & $7,727(23.4)$ & $15,796(22.8)$ \\
\hline 가구풍요도 (점) & & & $* *$ \\
\hline 상(6-9) & $11,919(33.0)$ & $10,512(31.8)$ & $22,431(32.4)$ \\
\hline 중(3-5) & $20,104(55.6)$ & $18,734(56.7)$ & $38,838(56.1)$ \\
\hline 하(0-2) & $4,113(11.8)$ & $3,813(11.5)$ & $7,926(11.5)$ \\
\hline Mean $\pm S D$ & $4.67 \pm 1.84$ & $4.64 \pm 1.79$ & $4.65 \pm 1.82 * *$ \\
\hline 아버지의 교육 수준 & & & $* *$ \\
\hline 대졸 이상 & $16,166(44.7)$ & $14,691(44.4)$ & $30,857(44.6)$ \\
\hline 고졸 & $13,246(36.7)$ & $12,843(38.9)$ & $26,089(37.7)$ \\
\hline 중졸 & $2,130(5.9)$ & $1,898(5.794)$ & $4,028(5.9)$ \\
\hline 모름 & $4,595(12.7)$ & $3,627(11.0)$ & $8,222(11.9)$ \\
\hline 어머니의 교육 수준 & & & $\star *$ \\
\hline 대졸 이상 & $11,986(33.2)$ & $10,299(31.2)$ & 22,285(32.2) \\
\hline 고졸 & $16,988(47.0)$ & $17,337(52.4)$ & $34,325(49.6)$ \\
\hline 중졸 & $1,970(5.5)$ & $2,005(6.1)$ & $3,975(5.8)$ \\
\hline 모름 & $5,193(14.4)$ & $3,418(10.3)$ & $8,611(12.4)$ \\
\hline
\end{tabular}

**p<0.01 남녀 성별차 검정을 위한 카이제곱 혹은 $\mathrm{t}-$ 검정

$\mathrm{N}=$ 표본크기; $\%$ = 가중된 비율; $\mathrm{SD}=$ 표준편차 
<표 2> 가구풍요도 및 기타 사회경제적 지표 수준에 따른 흡연, 음주 발생률 (남자 $n=36,137$, 여자 $n=33,060)$

\begin{tabular}{|c|c|c|c|c|c|c|c|c|}
\hline & \multicolumn{2}{|c|}{ 흡연 } & \multicolumn{2}{|c|}{ 매일 흡연 } & \multicolumn{2}{|c|}{ 음주 } & \multicolumn{2}{|c|}{ 폭음 } \\
\hline & 남자 & 여자 & 남자 & 여자 & 남자 & 여자 & 남자 & 여자 \\
\hline & $\%$ & $\%$ & $\%$ & $\%$ & $\%$ & $\%$ & $\%$ & $\%$ \\
\hline 발생률 & 16.4 & $6.9 \dagger$ & 9.1 & $3.0+$ & 23.0 & $17.5 \dagger$ & 9.9 & $8.8 \dagger$ \\
\hline 주관적 가구 경제상태 & $\star *$ & ** & $\star \star *$ & $\star *$ & & $\star *$ & & ** \\
\hline 상 & 14.4 & 5.3 & 7.6 & 2.2 & 21.6 & 16.0 & 8.9 & 7.2 \\
\hline 중 & 15.6 & 5.8 & 8.4 & 2.3 & 21.7 & 16.0 & 9.1 & 7.9 \\
\hline 하 & 21.0 & 11.1 & 12.8 & 5.2 & 27.6 & 22.6 & 12.7 & 12.5 \\
\hline 가구풍요도 & & ** & ** & ** & ** & & & ** \\
\hline 상(6-9) & 16.4 & 5.9 & 8.5 & 2.4 & 24.4 & 18.1 & 9.8 & 8.5 \\
\hline 중(3-5) & 16.3 & 7.0 & 9.3 & 3.0 & 22.3 & 17.1 & 9.8 & 8.7 \\
\hline 하(0-2) & 16.9 & 9.6 & 10.2 & 4.4 & 21.9 & 18.0 & 10.4 & 9.5 \\
\hline 아버지의 교육 수준 & ** & ** & ** & ** & ** & ** & ** & ** \\
\hline 대졸 & 13.7 & 5.1 & 7.0 & 1.9 & 21.3 & 15.1 & 8.4 & 7.0 \\
\hline 고졸 & 19.0 & 8.0 & 11.2 & 3.5 & 25.6 & 19.8 & 11.7 & 10.3 \\
\hline 중졸 & 21.0 & 10.0 & 13.2 & 6.1 & 29.6 & 25.0 & 14.6 & 14.1 \\
\hline 모름 & 16.3 & 8.8 & 8.6 & 3.7 & 18.4 & 15.7 & 7.5 & 7.6 \\
\hline 어머니의 교육 수준 & ** & ** & $\star *$ & ** & ** & ** & ** & ** \\
\hline 대졸 & 13.9 & 4.8 & 7.0 & 1.9 & 21.5 & 14.4 & 8.4 & 6.8 \\
\hline 고졸 & 17.4 & 7.4 & 10.0 & 3.1 & 24.3 & 19.0 & 10.8 & 9.7 \\
\hline 중졸 & 23.0 & 9.9 & 15.0 & 5.2 & 31.5 & 24.8 & 15.6 & 13.4 \\
\hline 모름 & 16.3 & 9.2 & 8.8 & 4.0 & 18.8 & 15.6 & 7.7 & 7.3 \\
\hline
\end{tabular}

$* * \mathrm{p}<0.01$ 사회경제적 지표 수준별 남녀 성별차 검정을 위한 카이제곱 혹은 $\mathrm{t}$-검정

$\dagger \mathrm{p}<0.01$ 남녀 성별차 검정을 위한 카이제곱 혹은 $\mathrm{t}$-검정

\section{3. 사회경제적 수준과 흡연, 음주와의 관련성}

청소년의 사회경제적 수준과 흡연, 음주의 건강 행태와의 관련성 확인을 위해 다른 요인(거주 지 역, 학년, 학업성취, 부모와의 동거여부 및 주관적 건강수준)을 포함한 다중회귀분석 결과를 살펴보았 다<표 3><표 4>. 네 가지 사회경제적 수준 모두 청소년의 흡연, 음주 행태에 영향을 미치는 것으로 확인되었으나 그 방향은 상이하게 나타났다.

즉 청소년의 주관적 가구경제수준 및 가주 풍요 도의 경우 남녀학생 모두에서 경제수준 및 풍요도 가 낮은 경우의 청소년에서 경제수준 및 풍요도가 높은 그룹에 비해 흡연, 매일흡연, 음주, 과도 음주 위험이 낮았다. 반면 부·모의 교육수준의 경우 남
녀 모두에서 부·모의 교육수준이 낮을수록 흡연, 음주와 같은 불건강한 건강행태의 위험이 높음을 확인할 수 있었다.

먼저 '주관적 경제수준'을 살펴보면, 주관적 경 제수준이 '중' 또는 '하'에 속한 남학생은 '상'이라 고 응답한 남학생에 비해 흡연, 매일흡연의 비차비 위험(Odds ratio)이 약 0.73 0.85배 낮은 것으로 나 타났으며<표 3> 음주 및 과도음주 비차비 위험 (Odds ratio)이 또한 0.76 0.91배로 낮은 것으로 나 타났다<표 4>. 한편 여학생의 경우 주관적 경제수 준이 '중'에 해당하는 경우에만 '상'에 속한 여학생 에 비해 흡연, 매일흡연, 음주, 과도음주 비차비 위 험(Odds ratio)이 약 0.7 0.8배 낮은 것으로 나타났 으며 '하'에 속하는 경우에는 유의한 차이를 나타 
내지 않았다. 객관적 경제수준 지표인 '풍요도'의 경우 '중' 및 '하'의 그룹에 속한 남학생은 '상'그룹 에 속한 남학생의 흡연 및 매일흡연 위험(Odds ratio)보다 약 0.7 배 낮았으며 음주 및 과도음주의 위험에 있어서도 약 0.6 0.7배 낮은 것으로 나타났 다. 여학생의 경우 풍요도에 따른 흡연, 매일흡연 위험에 있어서 유의한 차이를 보이지 않았으나<표 $3>$ 음주 및 과도음주 위험은 풍요도가 '중' 및 '하 에 속하는 여학생이 '상'에 속하는 여학생의 약 0.7 배에 해당하였다<표 4>. 부의 학력의 경우, 부의 학력이 고졸 및 중졸이하에 해당하는 남녀 학생은 부의 학력이 대졸이상인 경우보다 흡연경험의 odds 위험은 각각 약 1.2 배(고졸: OR 1.21, 중졸이 하: OR 1.147) 매일흡연의 위험은 약 1.4 배(고졸: OR 1.35, 중졸이하: OR 1.36)였다. 여학생에서는
부의 학력이 고졸 및 중졸이하의 낮은 경우 흡연 의 위험은 약 1.3-2.0배(고졸: OR 1.28 , 중졸이하: $\mathrm{OR} 1.38$ ), 매일흡연 위험은 약 1.5-2.0배(고졸: $\mathrm{OR}$ 1.46 , 중졸이하: 1.97 )인 것으로 나타났다<표 3>. 음 주에 있어서도 부의 학력이 고졸 및 중졸이하인 남학생의 경우 대졸 학력 부의 경우보다 음주 위 험은 1.1배, 과도음주 위험은 약 1.2 1.3배에 해당 하였으며 여학생의 경우도 음주 위험은 1.2 1.4배 및 과도음주 위험은 약 1.3 1.5배에 해당하였다<표 4>. 모의 학력도 부의 학력과 유사한 양상으로 모 의 학력이 고돌 및 중졸 이하의 학생은 대졸 이상 모의 자녀인 경우보다 흡연, 음주 위험이 높게 나 타났으나 부의 학력의 영향보다는 뚜렷하지는 않 았다.

<표 3> 청소년의 흡연과 매일 흡연의 다중로지스틱 회귀분석 (남자 $n=36,137$, 여자 $n=33,060$ )

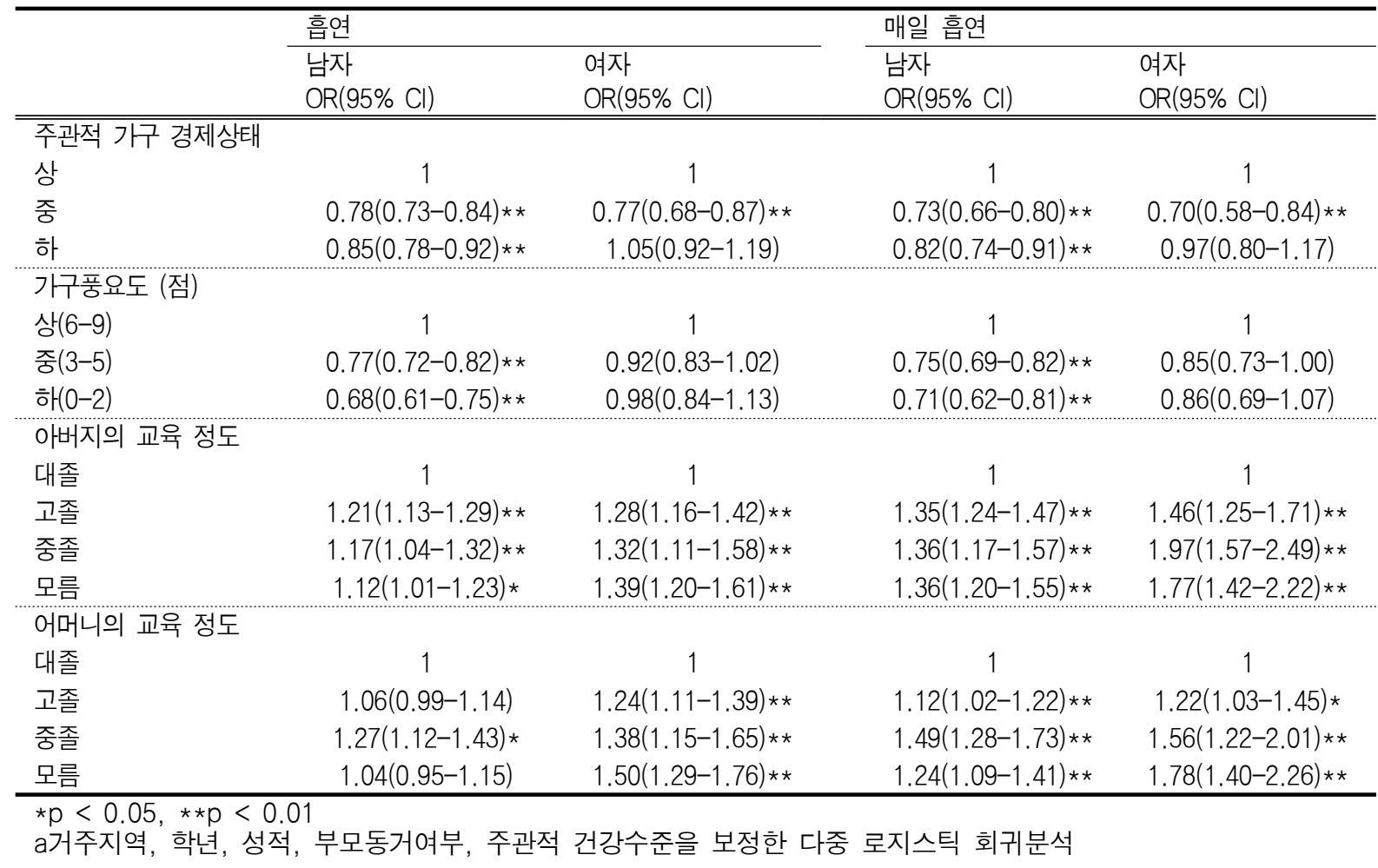


<표 4> 청소년의 음주와 폭음의 다중로지스틱 분석 (남자 $n=36,137$, 여자 $n=33,060$ )

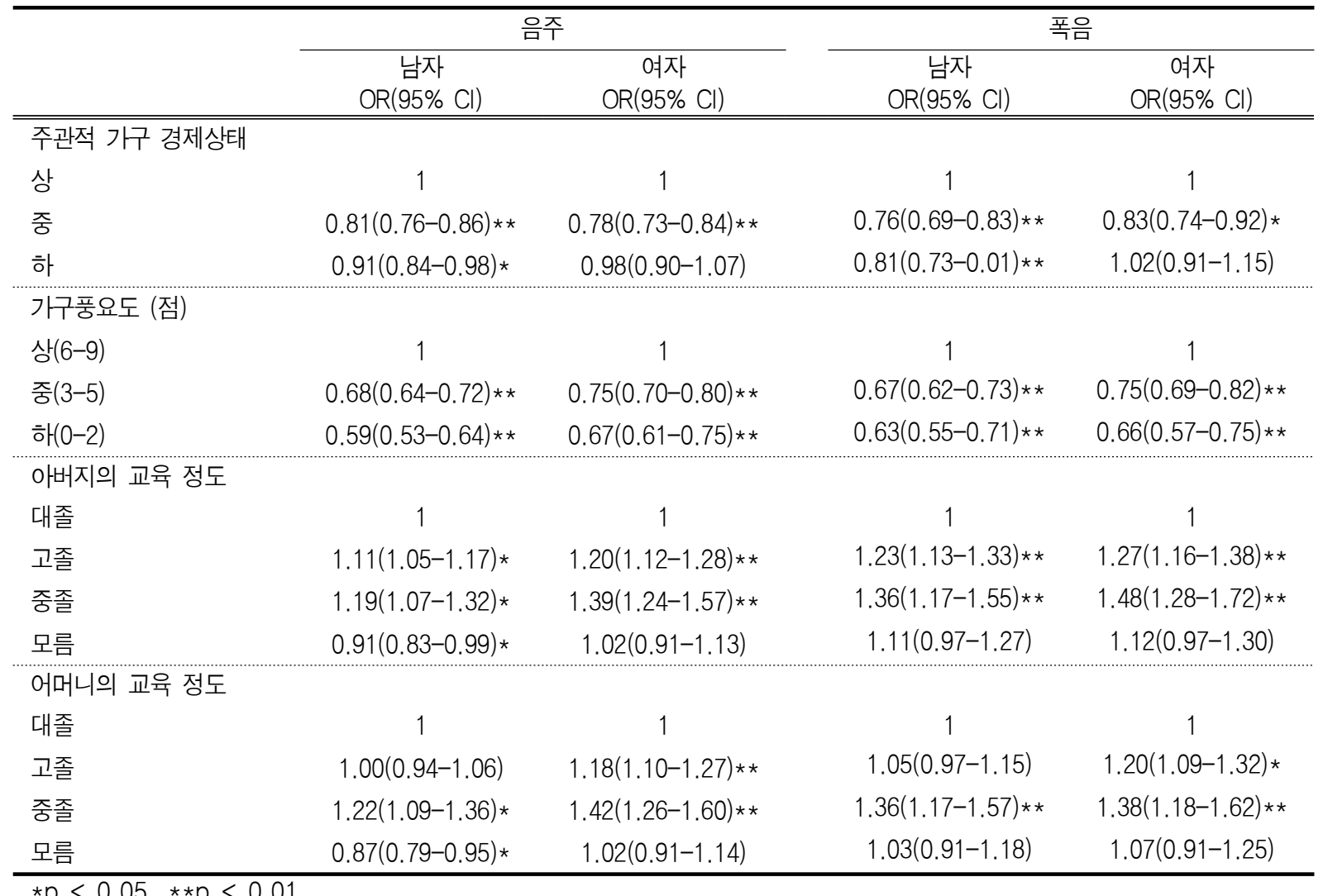

a거주지역, 학년, 성적, 부모동거여부, 주관적 건강수준을 보정한 다중 로지스틱 회귀분석

\section{$\mathrm{IV}$. 고찰}

본 연구에서는 '2009년 청소년 건강행태 온라인 조사' 원시자료를 이차 분석하여 청소년 부모의 사 회경제적 수준과 청소년의 음주, 흡연 행태의 관계 를 살펴보았다. 청소년 시기의 음주 및 흡연 행태 는 이후 성인기의 건강행태를 결정하는 중요한 요 인이 되므로 청소년의 음주 및 흡연율을 감소시키 기 위해서는 이에 영향을 미치는 요인을 세심히 살펴볼 필요가 있다. 그 중에서도 부모의 사회경제 적 수준이 미치는 영향은 미국, 유럽 등에서 활발 히 연구되고 있으나 우리나라에서 이를 자세히 분 석한 연구는 매우 부족한 실정이다. 부모의 사회경 제적 수준과 음주 또는 흡연과의 관련성에 관한
선행 연구에서 서로 다른 결과를 보고하고 있으며 본 연구 결과와 다른 연구도 상당수 존재한다. 본 고찰에서는 청소년 음주, 흡연에 영향을 미치는 가 구 풍요도와 부모의 교육 수준과 관련된 선행연구 결과와 본 연구 결과를 비교 분석함으로써 그 함 의를 논하고자 한다.

첫째, 본 연구 결과에서 가구의 경제수준을 측 정하는 지표에 해당하는 주관적 경제수준과 가구 의 물질적 조건을 측정한 풍요도의 경우 '중' 또는 '하'의 그룹에 속하는 청소년의 흡연, 매일흡연과 음주 및 과도음주 위험이 '상'의 그룹에 있는 청소 년에 비해 낮은 것으로 나타났다. 본 연구 결과와 같이, 경제 상태가 높을수록 알코올, 담배 등 물질 사용 (substance use) 비율이 높다고 보고한 연구 
들[13][14][15]이 있는 반면, 반대로 물질 사용 비율 이 낮다고 보고한 연구들 [16][17]도 있으며, 경제 상태와 청소년 음주 및 흡연은 아무런 관계가 없 다고 보고한 연구[18][19][20]도 있다. 가구 풍요도 와 관련하여, Pomerleau [17], Markina [22]는 본 연구와 같이 풍요도가 높을수록 알코올과 같은 물 질 사용 비율이 높다는 결과를 보고하였으며, Richtet [10]의 연구에서는 남자 청소년 집단에서만 가구 풍요도가 정적 상관이 있어 성별에 따른 차 이가 존재하는 것으로 나타났다. 이와 같이 서로 상반된 연구 결과가 다수 존재하는 것은 청소년의 사회경제적 위치를 측정하는 방법이 서로 다르기 때문으로 일부 해석될 수 있을 것이다. 예를 들면, 본 연구에서 주관적 경제 상태를 측정한 것과 달 리 박선희와 전경자[20]는 월평균 가구 소득으로 측정하였다. 다른 한 편으로는 경제수준이 낮을수 록 청소년의 흡연 및 음주가 높게 나타난 기존의 연구들[14][15][16]의 공통적 특성은 청소년의 흡연, 음주에 영향을 미치는 주요요인으로 확인되는 학 업성적, 부모와의 관계와 같은 혼란변인을 고려하 지 않았다는 점이다. 본 연구에서 다른 요인을 고 려하지 않고 단순히 주관적 경제수준 및 풍요도 수준에 따른 흡연, 음주 수준을 비교한 결과, 기존 연구와 같이 경제수준이 낮을수록 흡연, 음주의 위 험이 높게 나타났다. 따라서 본 연구에서 혼란요인 을 보정한 후 경제수준이 낮을수록 흡연, 음주 위 험이 감소하는 양상의 낮은 사회계층에 유리한 불 평등이 관찰됨에 주목할 필요가 있다. 이는 흡연 및 음주 행태에 대한 경제력의 영향을 반영하는 결과라고 해석할 수 있을 것이다. 청소년의 경우 성인에 비해 경제력이 상대적으로 제한되므로 재 정상태가 좋지 않은 청소년 집단에서 술과 담배에 대한 접근성이 떨어진다[14]. 술과 담뱃값이 우리 나라에 비해 상대적으로 매우 비싼 미국, 영국, 캐 나다 호주와 같은 $\mathrm{OECD}$ 선진국에서는 성인에서 도 가구 경제수준 및 가구 풍요도가 낮을수록 음
주 및 흡연율이 매우 낮게 나타났다[10]. 따라서, 우리나라의 경우 술과 담뱃값을 현재 수준보다 높 게 책정된다면 청소년의 음주 및 흡연율이 현재보 다 감소할 것으로 예상된다.

둘째, 본 연구 결과에서 부·모의 교육수준이 낮 을수록 청소년의 흡연율과 음주율의 위험은 높은 것으로 나타났다. 본 연구와 같은 결과를 보고한 연구 [23][24]가 있는데 그중에서도 특히 Droomers [23], Bloomfield [24]는 부·모의 교육수준이 낮을수 록 청소년의 폭음 비율이 높다고 하였다. Friestad [19]는 아버지의 교육수준이 어머니의 교육수준보 다 더 중요하다고 보고하였다. 이와는 반대로, 부 모의 교육수준이 청소년의 담배, 술과 같은 물질 사용과 관련이 없다는 보고 [13][19][20] 와 오히려 부모의 교육수준이 높을수록 담배, 술과 같은 물질 사용 비율이 높다는 보고[15]도 있다. 부모의 교육 수준이 청소년의 음주 및 흡연과 일관된 관련성이 보고되지 않는 것은 청소년의 음주 및 흡연이 부 모의 교육수준보다는 부모의 양육태도 또는 부모 감시 정도와 더 직접적 관련이 있기 때문으로 추 측할 수 있다. 왜냐하면, 부·모와의 애착관계, 영향 력 있고 긍정적인 부모의 양육태도, 친밀한 가족관 계가 낮은 음주 및 흡연율과 관련되어 있다는 일 관된 보고가 많기 때문이다. 한편으로는 부·모의 학력이 높을수록 흡연 음주의 위험이 낮게 나타난 본 연구의 결과는, 부모와의 애착관계, 영향력 있 고 긍정적인 부모의 양육태도 및 자녀와의 친밀한 의사소통 유지는 부모의 학력과 부적 상관성이 높 은 점이 반영된 결과로 해석할 수 있을 것이다. 특 히 흡연, 음주와 같은 건강행위는 무엇보다도 긍정 적인 부모의 양육태도 및 영향력이 중요하기 때문 이다. 본 연구에서 사용한 원시자료에는 부모와의 애착정도, 부모의 양육태도, 가족관계 친밀성 등이 포함되어 있지 않으므로, 더욱 정확한 결과 확인을 위해서는 청소년의 음주 및 흡연과 관련된 가족 관련 특성을 포함한 추후 분석이 요구된다. 
마지막으로, '청소년 건강행태 온라인 조사'에서 사용한 가구풍요도(FAS) 측정도구는 외국의 청소 년 건강연구에서 사회경제적 수준을 잘 반영해주 는 도구임이 입증되었으나 몇몇 문항은 우리나라 의 가구 풍요도를 측정하기에 적절치 않다고 보인 다. 즉, 자가용, 개인 방, 컴퓨터 소유, 가족 여행 횟수 등은 우리나라 청소년의 가구 풍요도를 민감 하게 나타내 주지 않을 수도 있는데, 예를 들어 유 럽 청소년의 $76.6 \%$ 가 컴퓨터를 소유한 것에 비해 우리나라는 $95 \%$ 의 청소년들이 컴퓨터를 소유하고 있으며[25] 국토가 좁고 자가용 보유 대수가 많아 쉽게 여행을 갈 수 있는 환경이기 때문에 현재의 가구풍요도 측정도구는 우리나라의 실정에 맞지 않다고 할 수 있다. 따라서 우리나라에 맞는 가구 풍요도(FAS) 측정 방법이 필요하다.

\section{V. 결론 및 제언}

청소년의 흡연, 음주의 건강행태와 사회경제적 위치 지표의 관련성을 탐색한 결과, 주관적 경제수 준, 풍요도, 부·모의 학력의 네 가지 사회경제적 위치 지표 모두 청소년의 흡연, 음주 행태에 영향 을 미치는 것으로 확인되었으나 그 방향은 상이하 였다. 즉 경제수준을 반영하는 청소년의 주관적 가 구경제수준 및 풍요도의 경우 남녀학생 모두에서 경제수준이 높은 경우 경제수준이 낮은 경우에 비 해 흡연, 매일흡연, 음주, 과도 음주 위험이 높은 양상을 나타냈다. 반면 부모의 교육수준의 경우 남 녀 모두에서 부모의 교육수준이 낮을수록 흡연, 음 주와 같은 불건강한 건강행태의 위험이 높음을 확 인할 수 있었다.

청소년기는 흡연, 음주와 같은 건강행태가 시작 되고 습관화되어 성인기 건강행태를 형성하는 주 요 시기이다. 게다가 본 연구결과에서 확인되었듯 이 사회경제적 상태는 청소년의 건강행태에 큰 영향을 주며 이러한 사회경제적 영향은 성인기의
건강불평등 결과로 이어질 가능성이 크다. 따라서 청소년의 사회경제적 건강격차에 대한 지속적인 모니터링과 추가적 연구가 지속적으로 필요하다.

\section{참고문헌}

1. 통계청(2012), 2012 청소년 통계 보도자료, 통계청, p.10.

2. 추헤경(2009), 중학생의 흡연 실태와 지식 및 태 도, 한양대학교 석사학위논문, pp.4-8.

3. 이흔주(2007), 청소년의 자아효능감과 음주기대, 한양대학교 석사학위논문, pp.6-7.

4. 보건복지부(2009), 청소년 음주의 사회경제적 비 용, 보건복지부 보도자료, pp.1-2.

5. Unger J.B., Sun P., Johnson C.A.(2007), Socioeconomic correlates of smoking among an ethnically diverse sample of 8th grade adolescents in Southern California, Preventive Medicine, Vol.44(4);323-327.

6. 남재봉(2011), 청소년 비행의 유형별 관련요인, 사 회과학연구, $\mathrm{Vol}, 28(2) ; 1-23$.

7. 곽연희(2011), 청소년 흡연에 영향을 미치는 부모 요인과 또래요인에 관한 연구, 신라대학교 석사 학위논문, pp.6-17.

8. 주미현(2004), 부모의 사회경제적 지위에 따른 청 소년의 건강행위 및 심혈관질환 위험요인 분석, 연세대학교 박사학위논문, pp.5-14.

9. Richter M., Leppin A., Nic Gabhainn S.(2006), The relationship between parental socio-economic status and episodes of drunkenness among adolescents: findings from a cross-national survey, BMC Public Health, Vol.28(6);289.

10. West P.(1997), Health inequalities in the early years: is there equalization in youth? Social Science Medicine, Vol.44(6);833-858.

11. Starfield B., Riley A.W., Witt W.P., Robertson J.(2002), Social class gradients in health during 
adolescence, Jouranl of Epidemiology and Community Health, Vol.56(5);354-361.

12. 교육과학기술부, 보건복지부, 질병관리본부(2010), 제5차 청소년 건강행태 온라인조사 통계, pp.1-15.

13. Hanson M.D. \& Chen E.(2007), Socioeconomic status and substance use behaviors in adolescents, Journal of Health Psychology, Vol.12;32-35.

14. Kuntsche E., Rehm J., Gmel G.(2004), Characteristics of binge drinkers in Europe, Social Science \& Medicine, Vol.59;113-127.

15. Humensky J.(2010), Are adolescents with high socioeconomic status more likely to engage in alcohol and illicit drug use in early adulthood?, Substance Abuse Treatment Prevention, and Policy, Vol.5;19.

16. Droomers M., Schrijvers C.T.M., Casswell S., Mackenbach J.P.(2003), Occupational level of the father and alcohol consumption during adolescence: Patterns and predictors, Journal of Epidemiology and Community Health, Vol.57;704 $-710$.

17. Pomerleau J., Pederson L.L., Ostbye T., Speechley M., Speechley K.(1997), Health behaviours and socio-economic status in Ontario, Canada, European Journal of Epidemiology, Vol.13;613-622.

18. Challier B., Chau N., Prédine R., Choquet M., Legras B.(2000), Associations of family environment and individual factors with tobacco, alcohol and illicit drug use in adolescents, European Journal of Epidemiology, Vol16;33-42.

19. Friestad D. \& Klepp K.I.(2006), Socioeconomic status and health behaviour patterns through adolescence: results from a prospective cohort study in Norway, European Journal of Public Health, Vol.16;41-47.

20. 박선희, 전경자 (2007), 중학생의 흡연시작 및 흡
연빈도에 영향을 미치는 요인, 한국청소년연구, Vol.18;5-27.

21. 김영미(2006), 청소년 음주와 흡연에 대한 가족구 조와 사회통제적 요인의 관계, 청소년학연구 Vol.13(6);151-178.

22. Markina A. \& Kask K.(n.d.), The effects of Family-related factors on alcohol and drugs consumption, Retrieved from http://www.aaapre vent.eu/doc/report\%20on\%20 family\%20factors.pdf

23. Droomers M., Schrijvers C.T.M., Stronks K., van de Mheen D., Mackenbach J.P. (1999), Educational differences in excessive alcohol consumption: The role of psychosocial and material stressors, Preventive Medicine, Vol.29;1-10.

24. Bloomfield K., Grittner U., Kramer S., Gmel G.(2006), Social inequalities in alcohol consumption and alcohol-related problems in the study countries of the EU concerted action "Gender, culture and alcohol problems: A multi-national study", Alcohol and Alcoholism, Vol.41;i24-i34.

25. Boyce W., Dellago L.(2008) Socioeconomic inequality. In: Currie C., Gabhainn G.N., Godeau E., Roberts C., Smith R., Currie D., Picket W., Richter M., Morgan A., Barnekow V. (eds) Inequalities in young people"s health: HBSC international report from the 2005/2006 survey, WHO Regional Office for Europe, Copenhagen.

접수일자 2012년 7월 17일

심사일자 2012년 8월 1일

게재확정일자 2012년 9월 28일 